\title{
The Growth of Family Medicine Resident Debt
}

\author{
Jennifer Edwards-Johnson, DO, MPH
}

(J Am Board Fam Med 2021;34:665-667.)

The history of people and their relationships with debt is an interesting one. Although some embrace debt as necessary or even opportunistic, for many, debt represents stigma-a scarlet letter and constant reminder of something that is owed or has been left incomplete. For many, debt is something that should carry shame. I grew up harboring ideas of good debt and bad debt. My education, the one that my parents instilled in me was essential but that they could not quite pay for, was good debt. Educational debt was not something to be ashamed of, rather, it was a marker of my future earning potential. Of course, I understood that this too would have to be paid back, but educational debt was respectable, at least. After 4 years of undergraduate training and (almost) 3 years of medical school, I watched as colleagues were driven to choose their specialty based on any number of factors. Lifestyle and indebtedness were high on the list, as were availability of mentorship and prestige. As I decided on family medicine, I knew that I was making a decision that would significantly lessen my earning potential, and admittedly this made my decision more complicated. By then I was sufficiently disabused of the notion that my

From the Michigan State University, Department of Family Medicine.

Funding: The author is supported by Grant Number K02HP30816 from the Health Resources and Services Administration (HRSA), an operating division of the U.S. Department of Health and Human Services. Its contents are solely the responsibility of the authors and do not necessarily represent the official views of the Health Resources and Services Administration of the U.S, Department of Health and Human Services.

Conflict of interest: None.

Corresponding author: Jennifer Edwards-Johnson, DO, MPH, Community Assistant Dean, Flint Family Medicine, 788 Service Rd., B120 Clinical Center, East Lansing, MI 48824 (E-mail: jej2013@msu.edu).

\section{See Related Article on Page 663.}

debt was good or bad, but I still had a lot of it. Ultimately, I found myself making a decision that had less to do with respectability or debt, and more to do with choosing a career and a specialty that had my respect.

Family physicians play quarterback to the US health care system. We provide full-spectrum care, often to the most vulnerable patients. ${ }^{1-3}$ In the context of a national pandemic, we have served as a principal part of a public health delivery enterprise. There are not enough of us, ${ }^{4,5}$ we are underpaid, ${ }^{6,7}$, and suffer from burnout, ${ }^{8,9}$ but every day we find creative solutions to complex problems. Despite this service, Phillips et al describe a disturbing trend that can only lead to fewer of us being committed to this work. The debt of family medicine residents is rising rapidly, and perhaps more appalling, increases among those with remarkably high debt have almost doubled..$^{10}$ As an osteopathic family physician who graduated with a debt load that surpassed the median, I am unsurprised. Most of my co-residents had similar debt loads and felt that the debt incurred while pursuing a family medicine career could be most effectively tackled by pursuing careers outside of academic medicine or public service. Out of nine residents, I was the only one to enter academic medicine; consistent with current trends demonstrating that family medicine residents with high levels of indebtedness are less likely to choose jobs in federally qualified health centers, a Veterans Affairs facility, or academia. ${ }^{11}$

These shifts, a decrease in physicians pursuing both academic family medicine and service careers, have significant implications for an already struggling workforce. Despite the desperately needed growth in primary care physicians, the share of the physician workforce dedicated to primary care from 2005 to 2015 decreased from $44 \%$ to $37 \% .^{12}$ Current projections show a deficit of 21,000 to 55,000 primary care physicians by $2032 .{ }^{4}$ While several national family medicine organizations have 
set a goal of graduating $25 \%$ of US medical students by $2030,{ }^{5}$ fewer physicians pursuing academic careers means less mentorship for medical students; a key driver in determining specialty choice. An existing salary gap between physicians in academia and nonacademic family physicians exacerbates these challenges. ${ }^{13,14}$ Why should graduating students invest in a specialty that quite literally hinders their ability to invest in themselves?

While some workforce dynamics have shifted, many have worsened or remained unchanged. Physicians from backgrounds underrepresented in medicine (URiM) are more likely to practice primary care and serve the most vulnerable communities, ${ }^{15}$ but these physicians make up less than $13 \%$ of all active physicians despite comprising over $30 \%$ of the US population. ${ }^{15,16}$ Moreover, URiM physicians represent less than $10 \%$ of full-time academic faculty ${ }^{16}$ and are more likely to have significant educational debt, ${ }^{17,18}$ further complicating efforts to recruit and retain diverse students and representing an additional barrier to expanding diversity within primary care and addressing health disparities. Those who do enter academia are often disproportionately tasked with the work of achieving diversity efforts and taxed via isolation, lack of mentorship, and fewer opportunities for promotion. ${ }^{19,20}$ Ultimately, asking physicians from marginalized communities to continue to make choices that represent a disinvestment in their future career earnings is not a question of altruism, but rather an example of a lack of commitment to equity.

Family medicine gained my respect as a specialty with the strongest commitment to social justice. The health care of the nation has depended on this commitment, requiring family physicians to fund, through skyrocketing levels of personal debt, the delivery of quality health care to the most vulnerable populations. But as family physicians, we make these personal investments because we are committed. If primary care, and the physicians who provide this care, are truly valued resources, teaching hospitals, health care administrators, payers, and policymakers must prioritize similar investments. An equitable distribution of health care is one that prioritizes the health of everyone and distributes resources to those who need them, including primary care physicians. A commitment to social justice and equity should not be mutually exclusive from achieving adequate compensation free from disproportionately onerous liability. A commitment to equity should not subsidize the cost of providing the nation's health care with the debt of those we have already taxed.

To see this article online, please go to: http://jabfm.org/content/ 34/3/665.full.

\section{References}

1. Rodgers DV, Wendling AL, Saba GW, Mahoney MR, Brown Speights JS. Preparing family physicians to care for underserved populations: a historical perspective. Fam Med 2017; 49:304-10.

2. Bazemore A, Petterson S, Peterson LE, Phillips RL., Jr. More comprehensive care among family physicians is associated with lower costs and fewer hospitalizations. Ann Fam Med 2015;13: 206-13.

3. Grumbach K, Hart LG, Mertz E, Coffman J, Palazzo L. Who is caring for the underserved? A comparison of primary care physicians and nonphysician clinicians in California and Washington. Ann Fam Med 2003;1:97-104.

4. Dall T, West T, Chakrabarti R, Reynolds R, Iacobucci W. 2018. 2018 Update The Complexities of Physician Supply and Demand: Projections from 2016 to 2030 Final Report Association of American Medical Colleges.

5. Prunuske J. America needs more family doctors: the $25 \times 2030$ collaborative aims to get more medical students into family medicine. Am Fam Physician 2020;101:82-3.

6. Kane Leslie. Medscape Family Physician Compensation Report. Medscape. Available from: https:// www.medscape.com/slideshow/2019-compensationfamily-physician-6011329\#19. Published April 24, 2019. Accessed February 21, 2021.

7. Phillips RL, Jr., Bazemore AW. Primary care and why it matters for U.S. health system reform. Health Aff (Millwood) 2010;29:806-10.

8. Martin M. Physician well-being: physician burnout. FP Essent 2018;471:11-5.

9. Hansen A, Peterson LE, Fang B, Phillips RL. Burnout in young family physicians: variation across states. J Am Board Fam Med 2018;31:7-8.

10. Phillips JP, Peterson LE, Morgan Z, Bazemore A. Debt of family medicine residents continues to grow. Abstract in Press. J Am Board Fam Med 2021.

11. Phillips JP, Peterson LE, Fang B, Kovar-Gough I, Phillips RL., Jr. Debt and the emerging physician workforce: the relationship between educational debt and family medicine residents' practice and fellowship intentions. Acad Med 2019;94:267-73.

12. Health Affairs. Physician workforce trends and their implications for spending growth. Health Affairs Blog. Published July 28, 2017. Available 
from: 10.1377/hblog20170728.061252 D. Accessed February 25, 2021.

13. Medical Group Management Association. 2017 Provider Compensation and Production Report: Based on 2016 Survey Data. Englewood, CO: Medical Group Management Association; 2017.

14. O'Gurek DT, Pugno PA, Talley MA. Sustainable family medicine academic workforce: A study of Pennsylvania residency faculty. Fam Med 2012;44:545-9.

15. Xierali IM, Nivet MA. The Racial and Ethnic Composition and Distribution of Primary Care Physicians. J Health Care Poor Underserved 2018;29:556-70.

16. Association of American Medical Colleges. Diversity in Medicine: Facts and Figures 2019. https://www. aamc.org/data-reports/workforce/report/diversitymedicine-facts-and-figures-2019. Accessed February 21, 2021.
17. Association of American Medical Colleges (AAMC). AAMC Facts \& Figures 2016, Table 36. 2016. Available from: http://aamcdiversityfactsandfigures 2016. org/.

18. Toretsky C, Mutha S, Coffman J. Breaking Barriers for Underrepresented Minorities in the Health Professions Healthforce Center at UCSF. 2018. https://healthforce.ucsf.edu/publications/breakingbarriers-underrepresented-minorities-health-professions. Accessed February 19, 2021.

19. Campbell KM. Slow progress and persistent challenges for the underrepresented minority family physician. J Am Board Fam Med 2018;31: $840-1$.

20. Rodriguez JE, Campbell KM, Pololi LH. Addressing disparities in academic medicine: what of the minority tax? BMC Med Educ 2015;15:6. 